\title{
PERSEPSI MAHASISWA TERHADAP VIDEO MONOLOG SEBAGAI ALTERNATIF TUGAS DALAM PEMBELAJARAN DARING
}

\author{
Diah Anugrah Dipuja \\ Program Studi Pendidikan Biologi, Fakultas Keguruan dan Ilmu Pendidikan, \\ Universitas Riau, Pekanbaru, Indonesia \\ “diahdipuja@gmail.com \\ Received: July $31^{\text {st }}, 2020$ \\ Revised: August $05^{\text {th }}, 2020$ \\ Accepted: August $10^{\text {th }}, 2020$
}

\begin{abstract}
The purpose of this study was to determine students' perceptions of monologue videos as alternative tasks in online learning. Monologue videos are one of various online learning alternatives which are assumed to increase student activity and creativity in learning so that online learning becomes more effective. Information about student perceptions regarding the effectiveness of monologue videos in online learning is needed to develop online learning to become better. This research was conducted by giving a questionnaire via google form to Biology education students as research respondents. From the research that has been done, the results showed that the application of monologue videos by students is considered effective as an alternative to online learning because it could increase student activity, creativity and motivation. However, there were some challenges and obstacles such as difficulties in making video scripts and video editing as well as network constraints and internet quota. Thus, it can be concluded that the application of video monologues as an alternative task in online learning were considered effective by students and can be developed further in other subjects.
\end{abstract}

Keyword: online learning; perception; video monologue.

\section{PENDAHULUAN}

Pendidikan merupakan hak bagi seluruh warga Indonesia yang wajib diberikan oleh suatu negara.Mutu pendidikan yang sangat baik dapat menghasilkan manusia yang mempunyai sumber daya manusia yang baik pula, untuk di negara maju maupun berkembang perkembangan berdampak positif dan negatif dalam segala aspek termasuk aspek pendidikan. Kemajuan teknologi memberikan pengaruh yang cukup besar dalam proses pembelajaran di dalam era modern seperti sekarang.Kemunculan metode Pembelajaran Berbasis Komputer (PBK) yang dalam pelaksanaannya menggunakan kecanggihan dari perkembangan teknologi, dalam dunia pendidikan memungkinkan untuk dilakukannya pembelajaran jarak jauh.Wadah media yang digunakan dalam 
pembelajaran jarak jauh sekarang ini menggunakan sistem dalam jaringan atau yang biasa disebut daring.Pembelajaran dengan metode daring dapat diartikan sebagi suatu jaringan komputer yang saling terkoneksi dengan jaringan komputer lain, keseluruh penjuru dunia.

Media pembelajaran yang semakin berkembang merupakan bukti kemajuan teknologi pada proses pembelajaran. Salah satunya yakni media video pembelajaran.Video sebenarnya berasal dari bahasa Latin, video-vidivisum yang artinya melihat (mempunyai daya penglihatan); dapat melihat.Media video merupakan salah satu jenis media audio visual.Media audio visual adalah media yang mengandalkan indera pendengaran dan indera penglihatan.Video monolog merupakan contoh nyata media pembelajaran yang sudah mulai populer dikalangan pendidikan karena video mampu dinikmati oleh indera penglihatan maupun indera pendengaran.Video merupakan suatu medium yang sangat efektif untuk membantu proses pembelajaran, baik untuk pembelajaran masal, individual, maupun berkelompok (Daryanto, 2012a).

Pada saat ini pendidikan di Indonesia diharuskan untuk menerapkan pembelajaran daring dikarenakan adanya pandemi Covid-19. Hal serupapun tidak terkecuali dirasakan oleh mahasiswa di perguruan tinggi seluruh Indonesia.Untuk itu, dalam rangka pemenuhan pendidikan yang sejatinya sebagai hak mahasiswa untuk tetap memperoleh pendidikan, maka perkuliahanpun dilakukan secara daring. Salah satu media yang digunakan sebagai proses pembelajaran baik dalam memberi materi ataupun sebagai evaluasi tugas untuk mahasiswa yakni dengan video monolog. Alternatif ini diambil berdasarkan karakteristik dan kelebihan dari media pembelajaran video monolog yang sekiranya dapat menunjang pembelajaran secara daring.Sebagai alternatif pada pembelajaran daring, video monolog diharapkan dapat meningkatkan efektifitas pada pembelajaran daring.

Namun demikian dalam pembuatan video monolog diperlukan berbagai alat dan media elektronik untuk melakukannya. Sehingga kemampuan mahasiswa dalam penguasaan penggunaan alat juga kemampuan editing diperlukan. Selain itu, kemampuan mahasiswa dalam bermonolog juga penting agar video yang 
dibuat terkesan menarik. Hal itu tentu menjadi masalah bagi mahasiwa dalam membuat video monolog. Belum lagi kendala lain yang mungkin dialami oleh mahasiswa seperti keterbatasan jaringan. maka pertanyaannya adalah apakah penggunaan media video monolog sudah efektif sebagai alternatif pada pembelajaran daring bagi mahasiswa? Bagaimana peran video monolog sebagai alternatif tugas pada pembelajaran daring bagi mahasiswa?Apa saja tantangan dan kendala yang dialami mahasiswa saat melakukan pembelajaran dengan alternatif video monolog saat pembelajaran daring?

Sehubungan dengan hal tersebut tujuan dari artikelini adalahuntuk memaparkan berbagai persepsi mahasiswa yang timbul dari penerapan video monolog sebagai alternatif tugas pada pembelajaran daring baik dari aspek efektivitasnya, peranan maupun tantangan ataupun kendala yang dihadapi saat menggunakan video monolog saat pembelajaran daring.

\section{KAJIAN TEORITIS}

\section{Pembelajaran Daring}

Pembelajaran metode daring merupakan pembelajaran yang dilakukan dengan prinsip dalam jaringan yang disebut juga dengan E-learning. E-learning adalah teknologi informasi dan komunikasi untuk mengaktifkan siswa untuk belajar kapanpun dan dimanapun (Dahiya,2016). E-Learning sebagai sebuah skenario baru yang ditetapkan oleh pemerintah dirasa sangat sesuai untuk peserta didik dengan situasi dan kondisi pandemi, keterbatasan waktu keterbatasan tempat belajar, keterpisahan jarak secara geografis, dan keinginan peserta didik untuk belajar ditempatnya sendiri. Hal ini akan terpenuhi jika metode yang adalah ELearning. Dengan demikian, E-Learning telah memperbesar kesempatan bagi individu untuk mendapatkan pendidikan yang diinginkannya sekaligus mempercepat terciptanya masyarakat yang yang berpengetahuan (knowledge society) (Rochaety, 2008).

Penggunaan internet untuk keperluan pendidikan yang semakin meluas untuk negara-negara di dunia, merupakan fakta yang menunjukkaan bahwa dengan media ini memang dimungkinkan diselenggarakannya proses belajar 
mengajar yang lebihh efektif (Hardjito,2002). Istilah E-learning banyak memiliki arti karena bermacam penggunaan e-learning saat ini. Pada dasarnya, E-learning memiliki dua tipe yaitu synchronous dan asynchronous. Synchronous berarti pada waktu yang sama. Proses pembelajaran terjadi pada saat yang sama antara pendidik dan peserta didik. Hal ini memungkinkan interaksi langsung antara pendidik dan peserta didik secara online. Dalam pelaksanaan, synchronous training mengharuskan pendidik dan peserta didik mengakses internet secara bersamaan. Synchronous training merupakan gambaran dari kelas nyata, namun bersifat maya (virtual) dan semua peserta didik terhubung melalui internet.Synchronous training sering juga disebut sebagai virtual classroom. Asynchronous berarti tidak pada waktu bersamaan. Peserta didik dapat mengambil waktu pembelajaran berbeda dengan pendidik memberikan materi. Asynchronous training popular dalam e-learning karena peserta didik dapat mengakses materi pembelajaran dimanapun dan kapanpun.

\section{Video Monolog}

Video monolog merupakan dua kata yang terdiri ataas video dan monolog. Dalam Kamus Besar Bahasa Indonesia (KBBI), video merupakan rekaman gambar hidup atau program televisi untuk ditayangkan lewat pesawat televisi, atau dengan kata lain video merupakan tayangan gambar bergerak yang disertai dengan suara. Sedangkan monolog adalah istilah keilmuan yang diambil dari kata mono yang artinya satu dan log dari kata logi yang artinya ilmu. Monolog menurut Galih (2015) sebagai pembicaraan yang dilakukan dengan diri sendiri atau seorang pelaku tunggal dalam sandiwara yang membawakan percakapan seorang diri. Jadi dapat disimpulkan video monolog yaitu suatu video yang digunakan untuk merepresentasikan audio-visual secara satu arah tanpa ada reaksi antar pembicara dan pendengar. Video mnolog ini bisa berupa penjelasan materi atau tutorial untuk merancang sesuatu.

Menurut I Komang (2014) video monolog merupakan suatu media audiovisual yang menggambarkan suatu ekspresi seseorang yang ditampilkan oleh seseorang secara sendirian.Video monolog ini termasuk salah satu jenis 
media pembelajaran yang menggunakan kemajuan teknologi.Media pembelajaran sendiri berarti segala sesuatu yang dapat digunakan oleh pengajar dalam menyalurkan ataupun menyampaikan materi pembelajaran agar peserta didik semangat dalam belajar.

Video sebenarnya berasal dari bahasa Latin, video-vidivisum yang artinya melihat (mempunyai daya penglihatan); dapat melihat.Media video merupakan salah satu jenis media audio visual.Media audio visual adalah media yang mengandalkan indera pendengaran dan indera penglihatan.Video monolog merupakan contoh nyata media pembelajaran yang sudah mulai populer dikalangan pendidikan karena video mampu dinikmati oleh indera penglihatan maupun indera pendengaran.Video merupakan suatu medium yang sangat efektif untuk membantu proses pembelajaran, baik untuk pembelajaran masal, individual, maupun berkelompok (Daryanto, 2012b).

Video monolog ini merupakan bahan ajar noncetak yang kaya informasi dan tuntas karena dapat sampai ke hadapan siswa secara langsung. Karakteristik media video menurut Arsyad (2010) yaitu: (a) Bersifat linear; (b) Menyajikan visual yang dinamis; (c) Digunakan dengan cara yang telah ditentukan sebelumnya oleh perancang; (d) Merupakan representasi fisik dari gagasan real atau abstrak; (e) Dikembangkan menurut prinsip kognitif; (f) Berorientasi pada guru.

\section{METODE PENELITIAN}

Penelitian ini menggunakan metode survei jenis penelitian kuantitatif yang menggunakan data statistik deskriptif.Data yang digunakan dalam penelitian ini adalah data primer.Data primer adalah informasi yang diperoleh secara langsung oleh peneliti sesuai dengan faktor atau variabel yang dibutuhkan dalam penelitian ini.Data dalam penelitian ini diperoleh dengan membagikan kuesioner kepada mahasiwa.Tahapan penelitian dimulai dari mengidentifikasi video monolog sebagai alternatif dari pembelajaran daring dengan mengumpulkan data melalui pertanyaan-pertanyaan yang dibuat melalui google form dalam bentuk formulir pengisian angket respon Mahasiswaterkait video monolog sebagai alternatif dari pembelajaran daring yang dirasakan oleh mahasiswa. 
Kuesioner ditujukan kepada Mahasiswa Pendidikan Biologi, angkatan 2019 sebanyak 78 mahasiswa pada link yang disebarkan memalui aplikasi Whatsapp grouppada Kamis 11 Juni 2020 sampai Minggu 14 Juni 2020.Adapun teknik pengisian angket ini dimulai dengan meng-klik link yang telah disebarkan, kemudian link tersebut akan mengarahkan partisipan ke Google Formulir. Di sana tersedia 2 bagian formulir yaitu form pengisian biodata atau identitas responden berupa nama, prodi/fakultas, kelas, dll. Kuisioner terdiri dari pertanyaan terbuka dan tertutup bertujuan untuk memebaskan mahasiswa dalam menyampaikan persepsinya. Dari hasil responden didapatkan 67 tanggapan yang terekam melalui google form yang selanjutnya dianalisis oleh peneliti.

\section{HASIL PENELITIAN}

Berdasarkan penelitian yang sudah dilaksanakan terhadap video monolog pada pembelajaran, maka didapatkan data berupa persepsi mahasiswa dari beberapa aspek yang dijelaskan sebagai berikut

\section{Penerapan video monolog pada pembelajaran}

Berikut tabulasi hasil penelitian mengenai persepsi awal mahasiswa tentang video monolog dalam pembelajaran yang dirangkum dari beberapa pertanyaan dan disajikan pada tabel 1.

Tabel 1. Respon mahasiswa terkait video monolog.

\begin{tabular}{llcc}
\hline \multirow{2}{*}{ No } & \multicolumn{1}{c}{ Pertanyaan } & \multicolumn{2}{c}{ Tanggapan } \\
\cline { 2 - 3 } 1. & $\begin{array}{l}\text { Apakah pembelajaran dengan video } \\
\text { monolog efektif digunakan untuk }\end{array}$ & 40 responden & Tidak Setuju \\
$\begin{array}{l}\text { pembelajaran daring? } \\
\text { Apakah dalam pembuatan video } \\
\text { monolog terasa sulit? }\end{array}$ & 44 responden & 6 responden \\
3. & $\begin{array}{l}\text { Apakah dalam pembuatan video } \\
\text { monolog harus menyusun konsep } \\
\text { terlebih dahulu? }\end{array}$ & 49 responden & 1 responden \\
4. $\begin{array}{l}\text { Apakah dalam pembuatan video } \\
\text { monolog memerlukan tujuan khusus? }\end{array}$ & 50 responden & 0 responden \\
5alam pembuatan monolog, apakah \\
$\begin{array}{l}\text { perlu membaca beberapa contoh } \\
\text { monolog yang berkualitas? }\end{array}$
\end{tabular}


6. Apakah terdapat kendala yang dihadapi jika menggunakan metode video monolog dalam pembelajaran?

7. Apakah perlu membuat video monolog terlihat semenarik mungkin?

8. Apakah langkah-langkah dalam pembuatan video monolog terasa mudah?
50 responden 0 responden

50 responden 0 responden

8 responden 42 responden

Dari pertanyaan tersebut terlihat bahwa sebagian besar mahasiswa merasa pembelajaran dengan menggunakan video monolog dapat dikatakan sebagai alternatif pembelajaran daring.Hal ini menunjukkan bahwa pembelajaran daring dengan menggunakan video monolog memberikan dampak yang positif dan dapat diterima mahasiswa dengan baik.

\section{Efektifitas Video Monolog dalam Pembelajaran}

Dilihat dari persepsi mahasiswa terhadapa efektifitas dari video monolog. Menurut sebagian besar mahasiswa yang telah mengisikuesioner menyatakan bahwa pembelajaran daring dengan menggunakan video monolog berpengaruh dalam proses pembelajaran peserta didik (Tabel 2). Penggunaan video monolog berdampak positif jika video monolog tersebut merupakan video yang menarik dan mudahdimengerti oleh peserta didik maka akan menumbuhkan semangat belajar dan memudahkan pemahaman peserta didik terhadap suatu materi. Dari pertanyaan tersebut, sebagian besar mahasiswa setuju bahwa video monolog memotivasi dan meningkatkan kreativitas peserta didik.Dengan adanya video monolog, peserta didik dapat berimajinasi dan memahami materi dengan caranya sendiri.Penugasan mahasiswa untuk membuat sebuah video monolog secara tidak langsung membantu mahasiswa dapat berpikir kreatif dan memudahkan dalam memahami materi pembelajaran. Sebagian besar mahasiswa berpendapat bahwa mereka membuat video monolog tersebut semaksimal mungkin agar video monolog yang mereka buat dapat terlihat menarik.

Tabel 2. Persepsi mahasiswa terhadap efektifitas video monolog dalam pembelajaran.

No. Pernyataan/Pertanyaan Setuju Tidak Lainnya




\begin{tabular}{|c|c|c|c|c|}
\hline & & \multicolumn{3}{|c|}{ Setuju } \\
\hline 1. & $\begin{array}{l}\text { Video monolog dapat membantu peserta didik } \\
\text { dengan gaya belajar yang berbeda-beda. }\end{array}$ & 17 & 3 & 37 \\
\hline 2. & $\begin{array}{l}\text { Kreativitas akan berpengaruh terhadap } \\
\text { keefektivitas video monolog. }\end{array}$ & 41 & 1 & 15 \\
\hline 3. & $\begin{array}{l}\text { Semakin menarik video monolog yang dibuat } \\
\text { maka semakin banyak juga properti yang } \\
\text { harus digunakan. }\end{array}$ & 36 & 4 & 17 \\
\hline 4. & $\begin{array}{l}\text { Video monolog yang tidak menarik justru } \\
\text { membuat semangat belajar peserta didik } \\
\text { menurun. }\end{array}$ & 39 & 2 & 16 \\
\hline 5. & $\begin{array}{l}\text { Menurut anda durasi akan mempengaruhi } \\
\text { keektifitas video monolog. }\end{array}$ & 33 & 7 & 17 \\
\hline 6. & $\begin{array}{l}\text { Berapakah durasi yang efektif dalam sebuah } \\
\text { video monolog? }\end{array}$ & $\begin{array}{l}44 \\
(5-10 \\
\text { menit) }\end{array}$ & $\begin{array}{l}1 \\
\text { (>20 } \\
\text { menit) }\end{array}$ & $\begin{array}{l}12 \\
(10-20 \\
\text { menit) }\end{array}$ \\
\hline 7. & $\begin{array}{l}\text { Sebelum membuat video monolog sebaiknya } \\
\text { menyusun konsep terlebih dahulu }\end{array}$ & 56 & 0 & 1 \\
\hline 8. & $\begin{array}{l}\text { Video monolog lebih efektif daripada melalui } \\
\text { video conference }\end{array}$ & 9 & 9 & 39 \\
\hline 9. & $\begin{array}{l}\text { Video monolog yang menarik membuat } \\
\text { peserta didik merasa betah melihat berulang } \\
\text { kali }\end{array}$ & 40 & 1 & 16 \\
\hline 10. & $\begin{array}{l}\text { Video monolog memutuskan komunikasi } \\
\text { antara pendidik dan peserta didik. }\end{array}$ & 14 & 16 & 26 \\
\hline
\end{tabular}

Tantangan dan kendala dalam penerapan video monolog pada pembelajaran

Dibalik sisi keunggulan dari penerapan video monolog sebagai alternatif dari pembelajaran daring dalam pelaksanaannya terdapat juga kendala dan tantangan dalam implementasinya.Berdasarkan kuesioner berikut tantangan serta kendala yang dihadapi oleh mahasiswa saat menggunakan video monolog sebagai alternatif pembelajaran daring (Gambar 1). 
Tantangan apa yang kamu hadapi saat pembuatan video monolog pada saat pembelajaran daring?

67 tanggapan

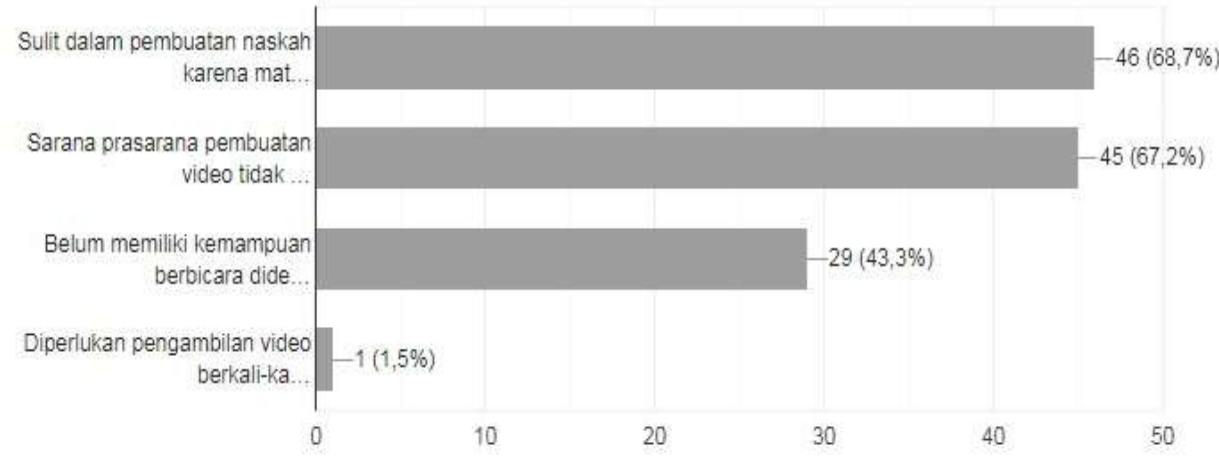

Gambar 1.Tantangan dalam penerapan video monolog dalam pembelajaran

Pada saat membuat video monolog, Apa saja kendala yang anda hadapi?

61 tanggapan

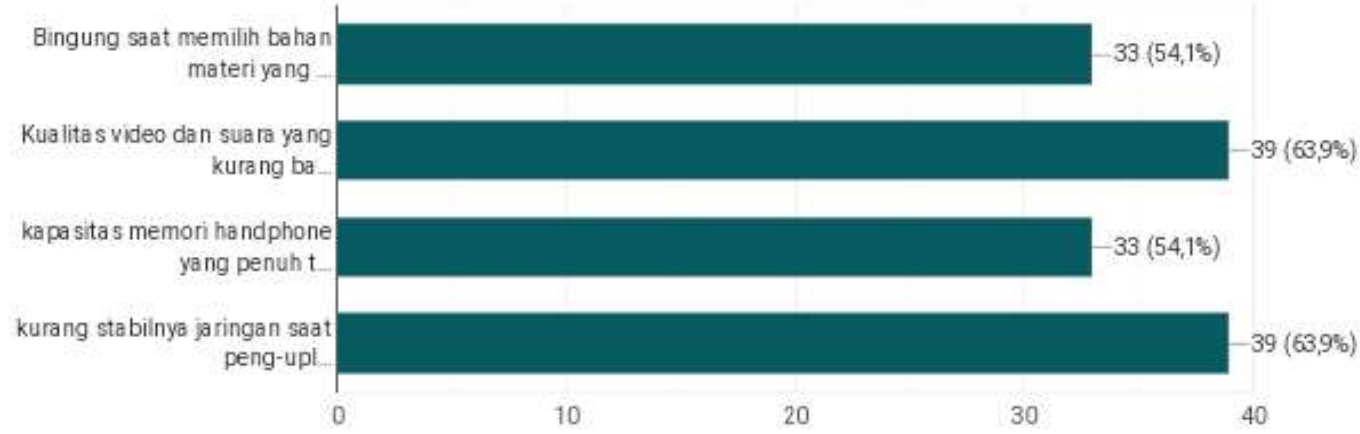

Gambar 2.Kendala dalam pembuatan video monolog dalam pembelajaran

Dari jawaban mahasiswa yang menyatakan bahwa pada saat membuat video monolog terdapat berbagai macam kendala yang menyulitkan mahasiswa untuk membuat sebuah video monolog. Pada saat membuat video monolog, kualitas video dan suara tentu harus diperhatikan sehingga menghasilkan video monolog yang baik. Saat pembuatan video monolog untuk pemenuhan tugas pembuatan video monolog yakni mahasiswa sulit dalam pembuatan naskah karena materi yang akan disampaikan belum dipahami benar. Dilihat dari persentase sebanyak $68.7 \%$.Selain itu sarana prasarana pendukung pelaksanaan 
pembuatan video juga kurang memadai (Gambar 2). Selanjutnya yaitu terkendala jaringan dan kuota untuk mendownload dan meng-upload video. Keterbatasan ini juga diakibatkan kondisi geografis dari tempat tinggal peserta didik yang timggal di daerah terpencil.Semakin jauh daerah tersebut dari perkotaan maka semakin lemah jaringan di daerah tersebut. Selain itu keterbatasan kuota yang mengharuskan para mahasiswa untuk mendownload serta mengupload video yang diberikan oleh para dosen tergantung juga pada ketersediaan kuota.

Menurut Anda, Video monolog yang seperti apa yang dapat menarik dan mudah dalam memahami materi pembelajaran?

67 tanggapan

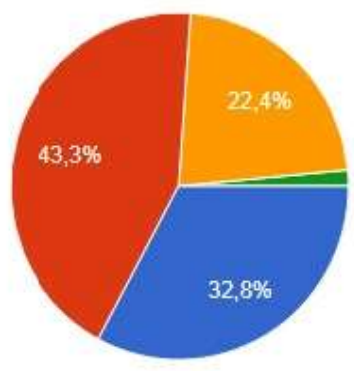

Video menggunakan animasi, mate yang yang disampaikan jelas dan kontekstual

Video yang membahas materi secara jelas dan ringkas, memuat beberapa latihan soal dan menggunakan bahasa kekinian

Video materi jelas dan kreatif

Singkat padat jelas

Gambar 3.Video monolog yang baik dalam pembelajaran

Dari hasil jawaban tersebut sebagian besar mahasiswa setuju bahwa video monolog yang baik yaitu video monolog yang memiliki cara penyampaian materi yang jelas dan menarik, tidak bertele tele, kualitas video dan suara harus jelas (Gambar 3), dan penampilan fisik dari penyampai materi harus rapi dan enak dipandang. Namun mahasiswa tidak terlalu setuju apabila video pembelajaran monolog yang baik menggunakan animasi.

\section{PEMBAHASAN}

Interaksi belajar secara daring dilakukan secara mandiri dengan memanfaatkan teknologi informasi dan pembelajaran yang telah disiapkan secara elektronik, dan dapat dilakukan kapan saja dan dimana saja.Pembelajaran daring hanya melibatkan pengampu atau pendidik dan peserta didik. Selama proses pembelajaran, peserta didik dibimbing dan difasilitasi secara daring oleh 
pengampuatau pendidik. Video monolog merupakan salah satu media pembelajaran yang digunakan sebagai alternative dalam pembelajaran daring.Video monolog adalah suatu video sebagai bentuk eksprsi karya cipta yang dilakukan oleh seorang penampil secara seorang diri.Dalam sebuah monolog, penampil mengambil satu atau beberapa topic atau tema tertentu kemudian membahasnya.Dalam pembahasan tersebut penampil dapat memasukkan subjektivitasnya, ekspresi emosi, suara, lagu, data, animasi, gambar, video, dan lain sebagainya.

Konsep video monolog online serupa dengan monolog klasik pada masa lalu, yang berbeda adalah pada tempat dan waktu penampilan serta soal penonton. Pada monolog klasik, penampil dan penonton hadir secara bersamaan di suatu tempat dan waktu tertentu, sedangkan pada video monolog online, penampil dapat membuat video tentang dirinya yang membahas suatu topik atau tema tertentu pada suatu tempat dan waktu tertentu tanpa harus ada penonton pada saat itu juga. Setelah itu penampil mengupload video monolog tersebut ke internet, untuk kemudian dapat dilihat dan diakses oleh penonton melalui komputer, laptop, handphone, dan peralatan lainnya yang dapat terhubung dengan internet.

Berdasarkan hasil dari penelitian yang telah dilakukan terhadap mahasisiwa program studi pendidikan biologi FKIP universitas Riau angkatan 2019, bahwasanya video monolog ini dinilai efektif dalam pembelajaran daring.Video monolog ini dinilai efektif sebagai alternative dalam pembelajaran daring dikarenakan kemudahan dalam memahami materi yang ada didalam video tersebut. Akan tetapi berdasarkan hasil penelitian tersebut, menurut mahasiswa bahwasanya dalam proses pembuatan video monolog terdapat tantangan dalam memahami konsep materi, mengedit video yang sangat banyak langkah-langkah dan tahapannya. Tidak hanya itu berbagai kendala yang dialami mereka dalam pembuatan video seperti merekam video tersebut, kendala jaringan, kendala kuota untuk mengupload video, kendala yang diakibatkan 
keterbatasan/kekurangan sarana dan prasaranayang dibutuhkan untuk membuat video monolog tersebut.

\section{Efektifitas video monolog dalam pembelajaran}

Monolog adalah percakapan dengan diri sendiri, sebagai monolog epik, penggambaran bukan menggambarkan akan situasi sebagai monolog pengamat, memperjelas komentar, seperti monolog konflik untuk membuat suatu keputusan dalam puncak alur. Efektivitas mengacu pada dua kepentingan yaitu baik secara teoritis maupun secara praktis, artinya adanya ketelitian yang bersifat komprehensif dan mendalam dari efisiensi serta kebaikan-kebaikan untuk memperoleh masukan suatu hal yang berkesandengan begitu serangkaian tugas yang sudah ditetapkan.Hasil riset menunjukkan bahwa durasi sangat mempengaruhi keefektifan dalam video monologberkisar 5-10 menit dengan penyampaian singkat, padat, dan jelas. Sehingga mudah dipahami dan tidak akan merasa bosan dengan durasi yang terlalu lama.

Pemberian video monolog sebagai alternatif pembelajaran daring dirasakan efektif bagi mahasiswa. Sebanyak $68,7 \%$ mahasiswa menganggap bahwasannya video monolog efekif dengan alas anpaham dengan materi yang disampaikan. Hal ini sejalan dengan hasil penelitian Tayade,dkk (2018) juga mendukung hasil ini yakni ia menyatakan bahwa "Video assisted learning is an effective medium for teaching learning in graduate medical education" yang artinya media pembelajaran dengan bantuan video adalah media yang efektif untuk diterapkan dalam proses belajar mengajar di perkuliahan pascasarjana kedokteran. Hal ini artinya dalam beberapa matakuliah penggunaan media video sebagai media pembelajaran dapat efektif untuk meningkatkan hasil belajar mahasiswa.

Melalui tugas video monolog mahasiswa juga dapat membangkitkan kreativitas, motivasi serta keaktifan mahasiswa.Mahasiswa menganggap bahwa belajar melaui video lebih mudah dibandingkan dengan melalui teks sehingga mereka terdorong untuk lebih aktif dalam berinteraksi dengan materi.Hal ini sejalan dengan Hamdani (2011) yang mengemukakan bahwa "video memaparkan 
keadaan real dari suatu proses, fenomena atau kejadian sehingga dapat memperkaya pemaparan". Begitupun Wijayanti dan Dwi (2017) yang menyatakan bahwa media video dapat menarik minat dan perhatian siswa untuk lebih aktif berpendapat dan menanggapi materi pembelajaran. Alternatif video monolog berbasis tugas atau proyek yang ditugaskan oleh dosen juga dapat untuk meningkatkan kreativits, motivasi, dan konsentrasi maha siswa dalam belajar. Saat diberikan tugas untuk membuat video maka mereka harus memahami materi yang ditugaskan, menyusun skenario video, hingga mengedit video agar video yang mereka buat lebih menarik dan lengkap akan materi.

Dengan adanya video monolog para mahasiswa juga memahami materi perkuliahan. Kemudahan dari penyajian video yang dapat diulang-ulang saat proses pembelajaran membuat siswa lebih mudah memahami isi dari video tersebut, selain itu penyajian sebuah materi yang terstruktur juga memudahkan siswa memahami materi khususnya tentang konsep (Sudiarta, 2016). Namun, perlu diketahui karakteristik video yang seperti apa yang dibutuhkan mahasiswa.

\section{Tantangan dan kendala dalam pembuatan video monolog}

Video monolog sebagai media pembelajaran menekankan pada kejelasan pesan, oleh karena itu dibutuhkan sarana dan prasarana yang lengkap untuk sajian yang komunikatif. Media pembelajaran melalui video ini tidak lepas dari kamera atau smartphone sebagai alat perekam video, teknik pengambilan video, pencahayaan yang cukup agar video tidak mengganggu mata penonton, suara narator yang jelas dan tidak mengganggu pendengaran penonton agar para penonton dapat mendengarkan materi dengan jelas dan dapat memahami materi, dan proses editing yang berguna untuk memendekkan atau memanjangkan durasi video. Durasi yang biasa digunakan untuk video sebagai media pembelajaran sekitar 20-40 menit karena mengingat kemampuan daya ingat dan kemampuan konsentrasi yang terbatas antara 15-20 menit.

Video tersedia untuk hampir seluruh jenis topik dan untuk jenis pembelajar di seluruh ranah pengajaran kognitif, afektif, kemampuan motorik, interpersonal. 
Pentingnya penyusunan konsep materi dalam rangkaian pembuatan video monolog. Menurut mahasiswa, penyusunan konsep materi ini sangatlah penting karena merupakan kunci utama dalam pemahaman peserta didik terhadap materi yang disajikan. Selain itu, sebagai narator yang menyajikan materi tentunya dengan penyusunan konsep materi akan mempermudah dalam menjelaskan dan menyampaikan materi serta mempermudah dan mempersingkat waktu dalam perekaman video.

Penulisan naskah video juga dimulai dengan identifikasi topik atau gagasan, dalam pengembangan instruksional, topik maupun gagasan dirumuskan dalam tujuan khusus kegiatan instruksional atau pembelajaran. Konsep gagasan, topik, maupun tujuan yang khusus kemudian dikembangkan menjadi naskah dan produksi menjadi program video. Rangkaian kegiatan untuk mewujudkan gagasan menjadi program video dilakukan secara bertahap melalui pembuatan sinopsis, treatment, storyboard, skrip atau naskah dan skenario atau naskah produksi. Naskah merupakan persyaratan yang harus ada untuk suatu program terkontrol isi dan bentuk sajiannya.

Dalam hal aplikasi yang digunakan oleh kebanyakan mahasiswa dalam membuta video monolog yakni pengeditan video dengan aplikasi Inshot. Inshot merupakan sebuah aplikasi yang bisa digunakan untuk melakukan pengeditan video dan foto. Aplikasi ini cukup digemari karena fitur di dalamnya yang cukup banyak, desain aplikasi yang mudah dipahami sehingga cocok bagi pemula dalam hal pengeditan video serta dapat dipakai gratis. Hal ini tentunya sangat mempermudah bagi guru atau mahasiswa yang ingin melakukan pengeditan sendiri secara gratis. Selain itu mahasiswa Pendidikan Biologi sebagian besar juga sering melakukan pengeditan melalui Smartphone. Oleh karena itu aplikasi Inshot ini sesuai apabila pengeditan dilakukan di Smartphone dengan kapapsitas penyimpanan yang relatif ringan.

Kualitas suara, video dan gambar ini sangat mempengaruhi bagi peserta didik dalam hal menarik minat belajar dan pemahaman peserta didik terhadap materi yang disajikan dalam video. Keunggulan media video juga terletak pada 
ukuran tampilan video sangat fleksibel dan dapat diatur sesuai kebutuhan pengguna, dan video juga merupakan bahan ajar non cetak yang kaya informasi dan lugas karena dapat sampai kehadapan siswa secara langsung atau melalui berbagai media digital seperti TV Led, Komputer, dan Handphone.

Selanjutnya menurut mahasiswa video monolog yang menarik dan dapat membangkitkan semangat belajar yaitu materi yang dijelaskan singkat, padat dan lugas, adanya animasi atau gambar untuk memperjelas maksud materi, warnawarni agar penonton tidak cepat bosan, memberikan motivasi, memiliki konsep yang unik, suara narator yang jelas, penyampaian narasi yang santai dengan sedikit humor serta narator yang tidak kaku, dan fleksibel atau mengikuti perkembangan zaman.

\section{SIMPULAN DAN REKOMENDASI}

Berdasarkan hasil penelitian yang dilakukan terhadap persepsi mahasiswa mengenai penerapan video monolog sebagai alternatif penugasan dalam pembelajaran daring, yaitu dapat disimpulkan video monolog sudah dapat dikatakan efektif dilaksanakan. Hal ini dikarenakan video monolog dapat membangkitkan kreativitas, motivasi serta keaktifan mahasiswa dalam pemebelajaran daring.Namun dari penerapan video monolog sebagai alternatif dari pembelajaran daring tidak terlepas dari tantangan dan kendala dalam pembuatan video monolog tersebut. Adapun tantangan yang paling dirasakan oleh mahasiswa yaitu sulit dalam pembuatan naskah karena materi yang akan disampaikan belum dipahami benar. Selain itu, Berbagai kendala juga menyertai pembelajaran daring menggunakan video monolog ini seperti sarana prasarana tidak memadai, belum memilki kemampuan berbicara di depan kamera, hingga diperlukan pengambilan video berkali-kali.

Rekomendasi yang dapat diberikan dalam penelitian ini adalah diharapkan untuk memberi pelatihan dan bimbingan dalam pembuatan video monolog untuk pembelajaran yang baik kepada mahasiswa melalui matakuliah yang ada. Maupun untuk pendidik seperti dosen dan guru yang sekiranya sangat diharapkan untuk 
bisa mengembangkan video monolog sebagai media alternatif untuk melaksanakan pembelajaran daring dan semoga kedepannya lebih banyak inovasi pembelajaran daring sehingga kendala yang dialami kini dapat teratasi di kemudian hari dalam rangka pengoptimalan pembelajaran daring demi mensukseskan visi dan misi pendidikan dalam menciptakan peserta didik yang cerdas, unggul, dan berprestasi.

\section{DAFTAR PUSTAKA}

Arsyad, A. (2010). Media Pembelajaran. Jakarta: PT Raja Grafindo Persada.

Dahiya, S., dkk. (2016). An eLearning System for Agricultural Education. Indian Research Journal of Extension Education, 12(3), pp.132-135.

Daryanto. (2012a). Inovasi Pembelajaran Efektif. Bandung: Yrma Widya.

Daryanto. (2012b). Media Pembelajaran. Bandung: PT. Sarana Tutorial Nurani Sejahtera.

Galih, dkk. (2015). Mengoptimalkan Hasil Belajar Mahasiswa Melalui Pengembangan Media Rumah Cerita Pada Mata Kuliah Tata Teknik Pentas Prodi Pendidikan Sendratasik UNU NTB.Jurnal IImiah Mandala Education. JIME, 1(2).

Hamdani. (2011). Strategi Belajar Mengajar. Bandung: Pustaka Setia.

Hardjito. (2002). Sistem Belajar Mandiri: Dapatkah diterapkan dalam pola pendidikan koonvensional?. Jurnal Teknologi Pendididikan, 10(4).

I Komang, D. M. (2014). Penggunaan Video Monolog Untuk Meningkatkan Kemampuan Bermain Peran Siswa Kelas XI IPB1 SMA Negeri 1 Sukawati. Jurnal Universitas Pendidikan Ganesha, 2(1).

Rochaety, E., dkk. (2008). System Informasi Manajemen Pendidikan. Jakarta: bumi aksara

Sudiarta, I. G. P., \& Sadra I. P. (2016). Pengaruh Model Blended Learning berbantuan Video Animasi tehadap Kemampuan Pemecahan Masalah dan Pemahaman Konsep Siswa. Jurnal Pendidikan dan Pengajaran, 49(2), 48-58.

Tayade, A., Tayade, S., Chalak, A., \& Srivastava, T. (2018). The impact of Video Assisted learning (VAL) on slow learners. International Journal of Biomedical and Advance Research, 9(1).

Wijayana, A., \& Yunita D. (2017). Pengaruh Media Video Pembelajaran Terhadap Hasil Belajar IPA Ditinjau dari Keaktifan Siswa. Jurnal Sosiohumaniora, 3( 2). 